\title{
ARTISTIC COMPREHENSION OF NATURE AND ENVIRONMENTAL AESTHETICS
}

\section{Nelya Filyanina ${ }^{1}$ \\ Viktorija Chitishvili ${ }^{2}$}

\section{DOI: https://doi.org/10.30525/978-9934-588-15-0-103}

\begin{abstract}
The article discusses the issues of comprehension of the essence of nature by representatives of art in order to harmonize the relationship "man-nature" and to find ways to resolve the modern era environmental crisis. Today, humanity faces a series of challenges, which, on the one hand, form new inquiries into art, create new social discourse and new perspectives of their artistic comprehension, on the other hand - change art itself, generating both new directions, styles, forms of art, and philosophical reflections on them. Understanding, recognition of the need to include nature in the aesthetic sphere and feeling of nature in the categories of the beautiful actualizes, as already been mentioned, the rethinking of the category of the beautiful and its opposition - the category of the ugly through the prism of human sensualit. The work investigates how philosophical reflections on the tendencies of changing of the role and function of art reveal themselves in the rethinking of the role of artistic comprehension of the world, the genesis of art and its functions. The feeling of organic life as a value creates a cognitive situation where the attitude to the biological object is closely connected to its ethical and aesthetic values. We have analyzed the features of modern bio-art and the formation of environmental aesthetics as a discipline. Bio-art gives an opportunity to demonstrate and, later on, to feel, rethink and live through the results of the creation of human hands, and at the same time to understand them as "echoes of the human imagination caused by the primordial thinking on the life and world of living organisms". Biological and evolutionary laws have become the object of study not only of scientists but also of artists who studies the achievements of modern biotechnology as a "fresh palette for
\end{abstract}

\footnotetext{
${ }^{1}$ D.Sc. in Philosophy, Candidate of Philological Sciences, Associate Professor Head of the Department of Humanities, National University of Pharmacy, Ukraine ${ }^{2}$ Teacher of the Foreign Languages Department, National University of Pharmacy, Ukraine 
artistic expression". The mission of bio-art, as it points out and moves into a more provocative and visual plane, is the question posed by the rapid development of synthetic biology as the science of constructing of living systems, which are described by the concept of "artificial life". Such issues include, in particular, the questions of the metaphysical, epistemological, and ethical status of life and "artificial life". It is shown that, unlike bio-art, ecological (environmental) issue refers to authentic nature as to a model to be guided in the creative process. One of the consequences of the environmental crises is the aesthetic depreciation of nature. However, the aesthetic depreciation of nature is also the cause of deepening of the environmental crises. The appeal to the theme of expanding of the methodological tools of scientific and natural sciences, understanding and application of methods of the humanities is relevant in the time of environmental and humanitarian crises, the interrelationship and interdependence of which are quite evident. In this sense, environmental aesthetics is an organic and integral part of the "humanitarian and environmental discourse." This factor of worldview formation, system of values and stereotypes of behavior of people of different age groups and social strata carries considerable educational and pedagogic potential. The central concept of ecological aesthetics is the concept of the beauty of nature, or the beauty inside the nature.

\section{Introduction}

For a long time, the representatives of different kinds of art have been raising the global problems of humanity in their work, anticipating them in advance.

Writers and artists are able to get ahead of time and allow people to reflect on topical issues in advance, and if necessary, call for appropriate action. Thus, the Ukrainian researcher O. Onishchenko, who studied this problem, gives, in her monograph "Writers as researchers: the potential of theoretical ideas (O. Wilde, T. Mann, A. France, I. Franko, S. Zweig)" Freud's idea that writers are ahead of scientists in their ability to grasp the problem, as they are able to see much deeper than they [7, p. 10].

The same applies to artists, musicians, representatives of synthetic arts. Accordingly, writers and artists cannot ignore the challenges of environmental crises in their anthropological dimensions.

Analyzing phenomenology and hermeneutics in the structure of philosophical and humanitarian education, V. Kebuladze notes, that the cross-cut- 
ting idea of Hans-Georg Gadamer's main work "Truth and Method" is that the truth can be presented to us not only through the application of the scientific method, but also through other spiritual practices: "For Gadamer himself it is a historical experience and art" [5, p. 52-53]. Therefore, exploring the causes and consequences of global environmental crises and identifying ways to overcome them the role of the art cannot be missed.

The purpose of this research is to review the attitudes of the humanities, writers, and artists to the current environmental crisis and ways of understanding and overthinking of the challenges of today, and to analyze their contribution to understanding the nature and relationships of man and the natural world, as well as ways of overcoming the environmental crisis in order to identify to what extent humanitarian and artistic understanding of the causes and effects of environmental crises. The ways of overcoming them can be used in developing of the concept of environmental education and environmental studying.

The process of searching and analyzing the answers to these questions is an important aspect of research on environmental issues, because the understanding of causes and ways of solving environmental crises is always pluralistic, that is, people see several reasons for these phenomena and ways to solve them.

They cover scientific, technological, economic decisions (approaches), and provide a view of the environment from the standpoint of moral, ethical and aesthetic values.

In the above-mentioned study, "Writers as Researchers: The Potential of Theoretical Ideas", its author pays attention to the significant contribution of artists to the development of the theoretical foundations of humanitarian knowledge, describing this situation with the idea of theoretical and practical parity. Its main idea is that "on the territory of world culture, a tendency has appeared, which showed the willing of the artists to peculiar research activity, leading to their direct appeal to outstanding theoretical achievements in the field of humanitarian knowledge." The active participation of writers and artists in the formation of environmental movements is a testament to the "multi-vector" of their creativity (by O. Onishchenko).

According to the stated theme of the study, we will be interested in the contribution of artists not so much to the study of the process of artistic creativity and cultural creation, as to understanding the ecological crisis as a factor opposing cultural creation, and to understand ways of overcoming the ecological crisis as a condition of preservation of man and culture. 


\section{Artistic comprehension of nature}

Historical and humanistic mission of the creator - writer, artist, musician is to raise the fundamental issues of human existence in his creative work. This thesis is precisely and succinctly formulated by Lina Kostenko: "A poet is a medium of history" [6, p. 550]. Nowadays the artists are called to draw people's attention to the contradictions of globalization, anticipating problems in advance, acting ahead and allowing scholars, politicians, experts, and public activists to reflect on raised topical issues in advance. Accordingly, writers and artists, the challenges of environmental crises in their anthropological dimensions can not be ignored. Analyzing phenomenology and hermeneutics in the structure of philosophical and humanitarian education, V. Kebuladze thinks that the crosscutting idea of the main work of Hans-Georg Gadamer "Truth and Method" is that truth can reveal itself before us not only as a result of the application of the scientific method, but in other spiritual practices: "For Gadamer himself - it is historical experience and art" [5, p. 52-53]. For this reason today the question of the role of art in understanding nature, the artistic reflection on ecological crises and the search for ways of harmonizing the connections between man and nature arises.

Finding and analyzing the answers to these questions is an important aspect of the study of environmental issues, since perceptions of the causes of environmental crises and finding the ways to overcome them are always pluralistic. It follows, firstly, from the fact that the environmental crises themselves are conditioned upon a whole cause system; secondly, any complex and multilayered problems, which include environmental problems of the present, imply the need for consideration and testing of various ways of overcoming them. They cover scientific, technological, economic decisions (approaches), as well as an environmental view from the standpoint of moral, ethical and aesthetic values [12, p. 23].

According to the research topic, we are first of all interested in the contribution of artists to understanding of the environmental crisis as a factor that opposes cultural cultivation and destroys a person, and understanding of the ways to overcome the environmental crisis as a condition of the preservation of man and culture.

It is known that nature is one of the greatest sources of artistic inspiration. Therefore, when such a source fades or shoals, it can not but concern the artist leaving him indifferent. 
In that way already at the end of XIX - early XX centuries in Europe clearly demerged groups of people who raised their voice in defense of nature, which was rapidly collapsing under the pressure of industrialization and urbanization, and who were concerned about the depletion of natural resources, the declining of the natural and cultural heritage, what became the cause of the internal crisis of a person, his discomfort, the loss of the meaning of being. Among them were writers, natural scientists, public figures, artists who suggested nature to be considered "as the source of harmony and stability, able to withstand the destructive power of industrial civilization that was rapidly changing the world." These voices not only contributed to the formation of idealized beliefs about the natural order, which should be kept in public life, but also urged society to take dynamic action to protect the archetype of virgin wildlife and natural and cultural heritage [1, p. 15].

"The essential feature of art, - said S. Grabovsky, - is the possibility of non-rational supplement of rational projects, rational orientations of worldview search" [2, p. 196]. Such projective determinants as dream, hope, faith in the future, ideal, expectation and aspiration, thinks the researcher, can concentrate around itself the spiritual, sensual, value-artistic pursuance of a person of the future development, of the prospects of mankind and its destiny. S. Grabovsky calls them a peculiar artistic "cluster". "As a specific product of spiritual and practical development of the world, - further develops his opinion S. Grabovsky, - the art reacts resiliently to changes in the field of human activity, shifts in the orientations and needs, consciousness and mentality of people" [2, p. 196]. Correspondingly, among the socio-cultural roles of art is the understanding of the spirit of time, the discerning and finding the typological worldview of the epoch, the prognosis of social prospects. Consequently, the researcher concludes, art is "an extremely sensitive barometer to detect sprouts of something new in social life, to find problems that humanity has yet to resolve" [2, p. 196].

Thus, the need to supplement the rational knowledge of the laws of the functioning of nature by understanding the meanings hidden in it and their interpretation (according to Blumenberg) is actualized, that should contribute to the deeper understanding of both the inner world of man and the world in which he lives. One way of such an understanding of nature may be to "read" nature in the same way as reading a book.

"Curbing passions, which were associated with the natural power, - writes O. Pavlova, - was the task of the whole logocentric philosophy. The impos- 
sibility of the full control over feelings in a rational way has caused despair among enlighteners. But in their rationalistic aspiration to critically make their minds absolute they did not realize that art has become not only a technique for developing, cultivating feelings, but also for controlling them. For control not so much in the sense of "purifying the senses" (Aristotle) and giving them moral, didactic content (as hoped the representatives of classicism), but also because the aesthetic absolutization leads to the desolation of feelings, as aestheticism ("Garden and Romantics") proves" [7, p. 129].

As a result, a person remains defenseless in front of "the abyss of his feelings" and can not rationally define their correctness. Therefore, this function is taken upon by art: "Art not only forms universal models of experience of feeling the world, but remains the only way of such an experience in the civilization process" [7, p. 129].

Nowadays humanity faces a number of challenges, which, on the one hand, form new demands for art, create a new social discourse and new projections of their artistic understanding; on the other hand, art itself changes, generating just as new directions, styles, forms of art, so philosophical reflections on them. The creation of new trends, forms and styles of art is associated with two fundamental factors of our time:

- rapid development of science, engineering and technologies, that insinuates into all spheres of being, modifying the nature, the surrounding world and human life, including art;

- degradation of the environment and destruction of landscapes, loss of plant and animal species, rapid development of urbanization processes, displacement of natural by artificial. All this carries such consequences as disturbance of balance not only in nature, but also in a person's state of health, violation of his emotional and psychological balance.

The art also responds sensitively to human conditions in a "depleted" artificial environment, trying, on the one hand, to redress the lost balance, attracting attention of a person and society to ecological crisis situations by means of art and thus appealing to the sensory-emotional sphere of a person; on the other hand, to perform a compensatory function, trying to compensate lost connections between man and nature resorting to artistic means.

Philosophical reflections on these tendencies that concern the change of the role and functions of art, reveal themselves in the rethinking and overestimation of the artistic understanding of the world, nature of art and its functions. 
To illustrate the above, we turn to bio-art and ecological (environmental) aesthetics. Bio-art, which began to develop and progress from the late 1980s, represents the school of artistic practices of manipulation of living organisms and life itself, using the scientific and technical tools of modern biology. Its development is closely connected with the development of biotechnologies, which not only extend the range of human transformation activity and provide new control range of biological processes, but also excite the philosophical idea of "critically redefining the vision of life and the permissible limits of manipulating it from the positions that a person determines in this world" [4, p. 246].

Studying bio-art, the Ukrainian philosopher Y.A. Ischenko believes that the artist, approaching to biotechnology, assumes the mission to help investigating probable models of the future through the use of new visual means. Contemporary bio-art directly manipulates living organisms, being unsatisfied with the traditional "commentarial" practices of visual art (painting, photography, screen and digital art). The basis of bio-art is the desire to understand the phenomenological aspects of manipulating life by practical consideration. If the artist is actually a seer, then some of these artists, as Y.A. Ischenko presumes, "prepare society for future changes in the field of biotechnology", or to liquidation of "Vedism" [4, p. 247], that is the inability to predict all the consequences of scientific development of the progress and development of biotechnology in particular. He also states that biological/evolutionary laws are now becoming the object of studying not only by scientists but also by artists who consider the achievements of modern biotechnology a "fresh palette for artistic expression" [4, p. 247].

Bio-art provides an opportunity to demonstrate and, therefore, feel, understand and experience the consequences of the man-made creation and the same time to understand them as "echo of human imagination caused by indigenous musings about life and sphere of living organisms" [4, p. 247].

Great stir among the public caused bio-art project by Eduardo Kac called «GFP Bunny» - green fluorescent rabbit Alba, which was developed using transgenic method, namely by microinjecting the gene of a jellyfish, which controls the synthesis of green fluorescent protein, into the DNA of a rabbit [9]. The rabbit's fur was shining green under the ultraviolet light. Bio-art idea was to bring a numerous beliefs of people in various bizarre creatures that do not exist in nature to life. In addition, in response to the stir among the public and media Eduardo Kac created a series of drawings, photographs, sculptures and digital 
images of «GFP Bunny». But the author of the project stressed the need to be careful creating new life forms, to respect and love the new creations. Although ethical issues always follow the artist's work in bio-art they arise with particular relevancy. It also enhances the interactive nature of bio-art.

Eduardo Kac himself even speaks of the emergence of transgenic art as the new kind of art that falls back upon genetic engineering techniques to transfer synthetic genes or genes of the same type into a genetic apparatus for "the creation of unique living creatures". The essence of these new "works of art" is defined not only by the emergence of the new forms of plants and animals, but, first of all, by the connections that arise between the artist, his creation and the public, the audience. Moreover, bio-art, according to E. Kac, may serve to increase global biodiversity [13]. In contradistinction from bio-art, ecological (environmental) aesthetics treats nature as an example, which should be followed in a creative process.

It is difficult to deny that nature in all its diversity: natural landscapes, mountains, forests, rivers, lakes, plants and animals, - has a significant aesthetic impact on a person. Against the background of environmental and humanitarian crises, interconnection and interdependence of which are already quite obvious, researchers are increasingly turning to the theme of expanding the methodological tools of scientific and natural knowledge and the application of methods of the liberal arts. As an example, ecological or environmental aesthetics can be mentioned [11].

\section{Ecological (environmental) aesthetics}

Russian research worker A.Yu. Guseva believes that environmental aesthetics is an organic and integral part of modern "humanitarian and ecological discourse" [3].

As any new field of research, environmental aesthetics undergoes the stage of formation of the framework of categories and concepts and definition of the subject, method and tasks of the research. First of all, it is evident that there is an absence of a single concerted term describing this area of research in national science, where, along with the term "ecological aesthetics", such concepts as "aesthetics of nature", "environmental aesthetics", "aesthetical ecology" are widely used. However, the specifics, the formation of their content, the range of issues described by them and the specifics of their functioning are not explained [8]. 
In particular, ecological aesthetics is defined as the aesthetics of the real world, comprising natural environment, cultural environment and engineered environment, that is, the environment that was formed under the influence of human activity. The term environmental aesthetics is usually used in English-language sources. The English term environmental in Ukrainian is translated both as "ecological" and as "environmental". Some scholars use these concepts as synonymous, but usually prefer the term "ecological".

A number of authors distinguish these concepts by associating the concept "ecological" with nature and natural environment, and "environmental" - with the environment that has undergone transformation as the result of human activity. So that during the XX century the term "environment" has become widely used not only in natural science, but also in the scientific-social, common cultural, socio-political lexicon, where the concept "surroundings", "environment" acquires various meanings. In the context of exacerbation of environmental crises, the concept "environment" is not so much associated with nature as comprises it only as a particular element, and is even opposed to it. The environment is also understood as a transformed nature, and in the conditions of rapid deterioration of the condition of natural ecosystems, the concept "environment" becomes synonymous with the destroyed, distorted nature $[1$, p. 60]. Those who associate the environment with nature insist on the need to preserve it in a "clean", flawless form, keeping human interference in such an environment to a minimum.

The counterposition is that social relations and human activity turn nature into the environment (urbanized, anthropogenic, social and cultural, recreational, etc.). Accordingly, the environment actually comprises just as the elements of nature and natural ecosystems so a human being and artifacts of human activity. The adherents of this approach emphasize the need to improve the "ways of reproducing the environment, control it and mitigate the negative effects of human activity" (soil pollution, water pollution, air pollution, deforestation, etc.), relying heavily on the opportunities of progress in science and technology, the improvement of public institutions, information distribution, education and enlightenment, etc. [1, p. 61].

During an analysis of the concepts "environment" and "nature" Dale Jamieson states that, considering the extremely broad meaning of the concept "environment", modern environmentalists are primarily concerned about the protection of nature. He also draws attention to the fact that very 
often these concepts are used as synonyms, although, in fact, the origins and history of each of them are significantly different $[12, \mathrm{p} .1]$.

Acceptance of the differences between nature and the environment will be the basis for us to use the terms "ecological aesthetics" and "environmental aesthetics" and their appropriate distinction. In those cases when this refers to aesthetic estimation of nature itself, we will use the term "ecological aesthetics" and when the issues is related to the aesthetics of environment that has suffered anthropogenic influences, we will use the term "environmental aesthetics". But while analyzing the general principles of this area of research, we will define it as an ecological (environmental) aesthetics.

Ecological (environmental) aesthetics to some extent opposes the imaginary world of art, although the borders between them are sufficiently conventional. The subject of the study of environmental aesthetics is the beauty of the environment [14, p. 17]. Yu. Sepanmaa considers environmental aesthetics as a part of environmental or ecological philosophy, which is the branch of philosophy, which is reflected just as on the natural science environmental research so on the social and cultural aspects of the interaction between man and the environment [14, p. 27]. This implies that to understand the beauty of the outside world, on the one hand, and to develop aesthetic standards of the organization of the human environment in accordance with the laws of beauty without understanding the beauty and harmony of its natural element is impossible.

E. Brady defines the ecological (environmental) aesthetics as a subdiscipline that belongs both to the branch of aesthetics and environmental philosophy [10]. She states that although the first significant philosophic discussions about natural aesthetics spread out in the XVIII century, aesthetic estimation of nature and landscapes (scenery) played a prominent role throughout the history of mankind.

The central category of aesthetics, as known, is the category of beauty, which is understood as an objective relationship between an aesthetic object and a subject that perceives it. In such a case, the aesthetic experience of a person plays an important role here. Therefore, the question about the need to define the concept of aesthetics of nature arises [3, p. 209]. A.Yu. Guseva proceeds from the definition of aesthetics not simply as "the philosophy of art" but primarily as a philosophical discipline about "sensually perceived form of expression", in other words the subject of aesthetic study is not only art, but also 
the entire sphere of axiological familiarization with the world, targeted on its estimation through the category of beautiful, by a person. This approach allows us to analyze all diverse and expressive forms of the environment as aesthetically significant objects. The researcher also states that collective consciousness perceives particular beautiful natural forms that have no author (unlike works of art) as the aesthetics of nature, and therefore they should be estimated in and of themselves or as a manifestation of "supernal loveliness" [3, p. 210].

The formation of ecological aesthetics as a discipline (or subdiscipline) falls on the 1960s. Although discussions about the aesthetics of nature began much earlier, exactly in the XXI century due to the development of ecological movements there were created the appropriate context and conditions, by virtue of which the need for a philosophical understanding of the connections between the aesthetic values of nature and their meaning in understanding of environmental problems was admitted. From the standpoint of philosophy, ecological aesthetics analyzes how aesthetic issues are related to the environment, natural objects, phenomena and processes (unlike works of art). Although ecological aesthetics considers the natural environment as its main subject, its field is constantly expanded by including it in a modified environment, that is, the one that has suffered human interference. That is why the subject of ecological aesthetics is also gardens, environment of everyday human existence, industrial objects, etc. The issue of ecological aesthetics is divided into three main directions [10]:

- aesthetical estimation of nature;

- theoretical and practical discussions about landscape design and aesthetical estimation of scenery, including romantic literature and poetry;

- essays on nature conservation and nature descriptions (nature writing).

Ecological (environmental) aesthetics seeks to define the criteria of "naturalness" of the environment compared to the purposeful human activity. In his work a person relies on the idea of harmony, style and form, and uses these categories to determine the success or failure of an artistic work, giving it a certain aesthetical estimation. It dramatically distinguishes human creativity from the processes taking place in the natural environment.

Many examples of implementation of the potential of applied ecological (environmental) aesthetics can be given relying on the experience of forming the urban environment, development of tourism industry, organization and management of national natural parks and other conservation areas. 
Ecological (environmental) aesthetics also has a significant teaching and educational potential as a factor of the mindset formation, a system of values and stereotypes of behavior of people of different age groups and social strata.

\section{Conclusions}

To find ways to overcome the ecological crisis of the present, researchers are increasingly appealing to the artistic comprehension of nature and artistic reflection on environmental crises.

The environmental challenges of the present, on the one hand, form new demands for art, create new social discourse and new projections of their artistic comprehension; on the other hand, art itself changes, generating just as new directions, styles, forms of art, so philosophical reflections on them. These issues fall under the competence of a new discipline - ecological (environmental) aesthetics.

Ecological aesthetics undergoes the stage of formation of the framework of categories and concepts and definition of the subject, method and tasks of the research. Ecological (environmental) aesthetics treats nature as an example that should be followed in a creative process. The central concept of environmental aesthetics is the concept of the beauty of nature, or the beautiful in nature.

It also should be noted that ecological (environmental) aesthetics - is quite new and not so much developed direction of philosophical research on the national territory. However, quite a wide range of aesthetical estimation of nature and the environment in general was actively investigated in Ukrainian philosophy just as in the context of the philosophy of culture, so in the context of ideological issues and spirituality.

Based on the consideration of the problem of nature and the environment through artistic means and eco-education, we can conclude that nature and the environment can differently affect human creativity: firstly, as the discovery and embodiment of natural inspiration, and secondly, as a demonstration of human benefits over nature or the taming of natural forces; thirdly, as a manifestation of human anxiety about the state of nature and the destruction of the world in which man lives.

Ecological crises of different scales and other related challenges of today, on the one hand, form new inquiries into art, creating new social discourse and new projections of their artistic comprehension, on the other - altering art itself, generating new directions, styles and forms art (for example, eco- 
music), as well as philosophical reflections on them, acting as an integral part of the "humanitarian and environmental discourse".

Forming a view of the environment and nature from a moral, ethical and aesthetic standpoint is a derivative of the multiplicity of causes of ecological crises and the pluralistic perception of their consequences and possible ways of overcoming problems. Therefore, in addition to scientific, technological, socio-economic and political approaches, approaches based on ethics (bioethics and environmental ethics) and aesthetics are becoming increasingly important.

Perceptions and experiences of the environment, nature and its individual components are connected to their ethical and aesthetic assessments, making ecological crises an alternative to cultural creation, and creatively understanding ways to overcome them as a condition of preserving man and culture. This idea is reflected in bio-aesthetics, bio-art and environmental aesthetics. The experience and creative understanding of ecological crises and ways of overcoming them through artistic means in the form of artistic "condensations" shows the ability of art to concentrate around itself spiritual-sensual, value-artistic aspirations of man to master the future, to the future of mankind, to the future of humanity recognition and identification of the typological worldview of the era, anticipation of social perspectives.

Bio-art represents the direction of artistic practices of manipulation of living organisms and life itself with the use of scientific and technical tools of modern biology, while environmental ecology refers to the authentic nature as a model to be guided in the creative process. Ecological aesthetics considers itself as the aesthetics of the real world, encompassing the natural, cultural environment and the constructed environment, that is, the environment formed under the influence of human activity. The principles of environmental aesthetics are in line with the need to recognize the value or value of nature. The use of aesthetic arguments in favor of environmental protection is described by the understanding of aesthetic protectionism.

One of the consequences of environmental crises is the aesthetic depreciation of nature. At the same time, aesthetic depreciation of nature can also be the cause of environmental crises deepening. The concept of "positive aesthetics of nature" is opposed to the aesthetic depreciation of nature, according to which the nature, which has not been subjected to human interventions, usually receives the highest aesthetic judgments based on the following theses: wild nature certainly has positive aesthetic qualities; negative aesthetic judgments 
about nature are inadmissible; everything in nature has the same aesthetic value; nature has maximum aesthetic value. At the same time, aesthetic protectionism and positive aesthetics of nature are affected by relativism or aesthetic pluralism, caused by the ambiguity and a considerable part of subjectivity in aesthetic assessments of nature and the environment. Therefore, the starting point of the analysis of the aesthetic process in assessments of nature, environment and human interaction with the environment should be not the opposition "beautiful - ugly", but the opposition "aesthetic - indifference".

Ecological (environmental) aesthetics has significant educational potential as a factor in the formation of outlook, value system and behavior of people of different age groups and social strata. Despite the discussions around the definition of the subject, methods, tasks of environmental aesthetics and its conceptual and categorical apparatus, environmental aesthetics begins to take a prominent place in educational programms and courses as an integral part of the curriculum for architects, designers, designers urban planners and more.

Although ecological (environmental) aesthetics is a rather new and not-developed area of philosophical research in the domestic territories, a wide range of issues of aesthetic appreciation of nature and environment is actively investigated in Ukrainian philosophy both in the context of the philosophy of culture, and in the context of worldview and worldview spirituality.

Ecological (environmental) aesthetics is included into educational programs in philosophy, aesthetics, eco-philosophy in close connection with ecological ethics, as well as in educational programs in urban science, architecture, landscape design and more. Understanding of the beauty of nature creates a powerful motivation to protect it (aesthetic protectionism). At the same time, aesthetic values do not play a proper role in the protection and reproduction of nature, giving way to material values, and the use of aesthetic arguments is complicated by the idea of subjectivity and relativity of perception of the beauty of nature. Ukrainian researchers, environmentalists and educators are well aware of the limitations of scientist-technocratic and pragmatic models of perception of the world in general and of nature in particular. More desirable is the scientific and artistic paradigm, which corresponds to the current tendencies of the combination of rational, emotional, sensual and value in the comprehension of the world. It is based on the synthesis of philosophy, science and art. The unity of ecological and aesthetic education can be realized within the scientific and artistic paradigm. 


\section{References:}

1. Ghardashuk T.V.(2005). Konceptualjni parametry ekologhizmu [Conceptual parameters of ecology]. Kyiv: Vydavecj PARAPAN. (in Ukrainian)

2. Kyseljov M.M., GhardashukT.V., Ghrabovsjkyj S.I. (2014). Zaghaljnokuljturnyj kontekst ghumanistychnoji transformaciji vymiriv naukovogho doslidzhennja [The general cultural context of the humanistic transformation of the dimensions of scientific research]. Etyka nauky: vyklyky suchasnosti: monoghrafija [Ethics of science: challenges of the present: monograph]. Nizhyn: PP Lysenko M.M., pp. 181-246.

3. Guseva A.Yu. (2012). Ekologicheskaya estetika kak prevrashchennaya forma estetiki prirody [Ecological aesthetics as a transformed form of aesthetics of nature]. Terra Humana, no. 3, pp. 209-213.

4. Ishhenko Ju.A. (2010). Bioghnosys: podvijnyj topos zhyttja [Biognosis: the double topos of life]. Kyiv: CGhO. NAN Ukrajiny. (in Ukrainian)

5. Kebuladze V. (2013). Fenomenologhija i ghermenevtyka u strukturi filosofsjkoji i ghumanitarnoji osvity [Phenomenology and hermeneutics in the structure of philosophical and humanitarian education]. Filosofsjka dumka: Ukrajinsjkyj naukovo-teoretychnykh chasopys, no. 5, pp. 52-53.

6. Kostenko L.V. (1989). Vybrane [Favorites]. Kyiv: Dnipro. (in Ukrainian)

7. Onishhenko O.I. (2011). Pysjmennyky jak doslidnyky: potencial teoretychnykh idej (O. Uajljd, T. Mann, A. Frans, I. Franko, S. Cvejgh): monoghrafija [Writers as researchers: the potential of theoretical ideas (O. Wilde, T. Mann, A. France, I. Franco, S. Zweig): monograph]. Kyiv: instytut kuljturologhiji NAM Ukrajiny. (in Ukrainian)

8. Pavlova O. (2013). Aktualjnistj estetychnogho [The relevance of the aesthetic]. Filosofsjka dumka: Ukrajinsjkyj naukovo-teoretychnyj chasopys, no. 5, pp. 124-133.

9. Jakovenko M.L. (2012). Filosofija: konspekt lekcij: Zbirnyk pracj [Ecological aesthetics as an actual direction of modern culture]. Filosofija: konspekt lekcij: Zbirnyk pracj (electronic collection) Kyiv, 750 p. Available at: http://www.nbuv.gov.ua/portal/Soc_Gum/phd/2008_9/jakovenko.pdf9 (accessed 29 October 2019).

10. BioArt: Is It Art? Is It Science? Is It the Future? URL: http://mashable.com/ 2013/10/29/cutpastegrow-bioart/ (accessed 29 October 2019).

11. Brady Emily (2009). Environmental Aesthetics. Encyclopedia of Environmental Ethics and Philosophy. Ed. J. Callicott and Robert Frodeman. Vol. 1. P. 313-321. URL: http://plato.stanford.edu/entries/environmental-aesthetics/ http://iseethics.files.wordpress.com/2013/01/brady-emily-environmentalaesthetics.pdf (accessed 29 October 2019).

12. Environmental Aesthetics. Stanford Encyclopedia of Philosophy URL: http://plato.stanford.edu/entries/environmental-aesthetics/ (accessed 29 October 2019).

13. Jamieson D. (2008). Ethics and the Environment: An Introduction. Cambridge, $221 \mathrm{p}$.

14. Kac E. Transgenic art. URL: http://www.ekac.org/transgenic.html (accessed 29 October 2019).

15. Sepänmaa Y. (1993). The Beauty of Environment: A General Model for Environmental Aesthetic. Denton, Texas, $191 \mathrm{p}$. 